African Journal of Economics and Sustainable Development

ISSN: 2689-5080

Volume 4, Issue 3, 2021 (pp. 61-71)

www.abjournals.org

\title{
IMPACT OF PUBLIC CONSUMPTION ON ECONOMIC GROWTH
}

\author{
Naftaly Mose \\ University of Eldoret, Kenya
}

Cite this article:

Naftaly Mose (2021), Impact of Public Consumption on Economic Growth. African Journal of Economics and Sustainable Development 4(3), 61-71. DOI:

10.52589/AJESD_TYRZ1J6S

\section{Manuscript History}

Received: 2 Sept 2021

Accepted: 22 Sept 2021

Published: 27 Sept 2021

Copyright $\odot 2020$ The Author(s)

This is an Open Access article distributed under the terms of Creative Commons AttributionNonCommercial-NoDerivatives 4.0 International (CC BY-NC-ND

4.0 ), which permits anyone to

share, use, reproduce and

redistribute in any medium,

provided the original author and source are credited.
ABSTRACT: Faced with the financial crisis and global economic recessions, Africa governments have rediscovered the importance of economic policy instruments. They use it to rescue the bankrupt banks, and to make more economic activity to carry back recession. But now there's a backlash demanding that the deficits used to create the stimulus must be reduced by cutting public consumption spending on a grand scale. Hence the target of this study is to explore the role of public consumption expenditure on economic process in East African geographic region. The study will use panel ordinary least square estimation technique to attain the study objective. The study has identified consumption expenditure to be negatively associated with growth. This study recommends few funds should be channeled to public consumption programmes and sectors.

KEYWORDS: Economic Growth, Public Finance, Public Consumption Expenditure, Fiscal Policy 


\section{INTRODUCTION}

Economic scholars agree that there are circumstances within which lower levels of public consumption spending would enhance economic activities and other circumstances during which higher levels of public consumption spending would be desirable. If consumption government spending is zero, presumably there'll be little or no economic activities because enforcing contracts, protecting property, and developing infrastructure would be very difficult (Kakar, 2011). In other words, some consumption public spending is required for the successful operation of the rule of law (Mitchell, 2005).

The new-Keynesians present the multiplier effect and argue that the rise in consumption expenditure will increase demand, consumption and thus accelerate economic process further. In line with the neo-classical economic scholars presents a special response and argue that reducing the role of non-public sector by crowding-out effect is very important because it reduces the inflation within the economy; increase public debt, increases the interest rate which reduces inflation within the economy further as output (Barro, 1990; Kakar, 2011).

Consumption public spending comprises expenditure items which are recurring within the process of delivering government economic and social services. Wages, subsidies, operation and maintenance, pension and debt servicing are among the foremost components of recurrent expenditure (Waweru, 2021). These are broadly considered to be consumable items, the advantages of which are consumed or exhausted within each year. Both components involve exhaustive and transfer expenditures (Barro, 1991). Generally, in East Africa consumption public expenditure has been increasing at high rate than economic growth (EAC, 2011). This trend is inconsistent with the East Africa's government's commitment to form service provision a priority for a broader-based growth.

\section{Statement of the Problem}

The steady rise of state consumption expenditure for several years, in most countries, demonstrates a commanding link between consumption spending and economic activities. However, most studies on the connection demonstrate conflicting results. These contrasting results provided a gap that required further study particularly in East African geographic area economies. This research, therefore, adopts the question on whether or not consumption public spending has contributed to economic process in East African geographic region economies.

\section{Objectives of the Study}

The objective of the study is to determine the impact of public consumption expenditure on economic growth of East African states

\section{Research Hypotheses}

There is no significant impact of public consumption expenditure on economic growth in East Africa states. 


\section{THEORETICAL LITERATURE}

The German economist Adolf Wagner (Backhaus, 1997) advanced his 'law of rising public expenditures' by analysing trends within the growth of state expenditure and within the size of public sector in many countries of the planet. Wagner's law of skyrocketing public expenditure postulates that; (i) the extension of the functions of the states results in a rise publically expenditure on administration and regulation of the economy; (ii) the event of contemporary industrial society would produce to increasing political pressure for social progress and require increased allowance for social consideration within the conduct of industry (iii) the increase in government expenditure are quite the proportional increase within the value (income elastic wants) and can thus lead to a relative expansion of the general public sector. Wagner's model, while containing many insights, suffered from different criticisms. These critics view Wagner's predictions as essentially explaining causes of increase in expenditure and argue that the connection lacks a firm theoretical basis. Wagner assumed away the issues of public choice by employing an organic theory of the state. Thus, the state was assumed to behave as if it were a personal existing and making decisions independently of the members of society (Brown \& Jackson, 1996).

According to the Keynesian theory, public expenditure can contribute positively to economic expansion. Hence, a rise within the government consumption is probably going to guide to a rise in employment, profitability and investment through multiplier effects on aggregate demand. As a result, government spending augments the total demand, which provokes an increased output betting on expenditure multiplier (Romer, 1996). The opponents of this approach stipulate that public consumption crowds out private investment, discourages economic process within the short-run and diminishes capital accumulation within the longrun.

\section{Empirical Literature}

Empirical research studies have produced inconclusive result. For instance, some scholars found a negative relationship between economic process and consumption expenditure (Akpan, 2005; Romer, 1990; Gisore et al., 2014), others indicate that the result's a positive relationship (Korman \& Bratimaserene, 2007; Gregorious \& Ghosh, 2007). A significant number of studies (Akpan, 2005; Romer, 1990) are dispensed on the link between government expenditure (aggregate) and economic process. However, majority of these studies (Akpan, 2005; Romer, 1990) don't examine the effect of consumption expenditure on economic process. Additionally, a number of the studies made use of ordinary least squares (OLS) approach and were cross-country or time series based which are vulnerable to many econometrics disadvantages like multicolliniality and omitted variable bias. This study utilised panel OLS estimation which addresses the issues of omitted variable bias and multicolliniality. As a result of the above-mentioned factors, the researcher found it necessary to devolve into the study so on fill the prevailing research gap. 
African Journal of Economics and Sustainable Development

ISSN: 2689-5080

Volume 4, Issue 3, 2021 (pp. 61-71)

www.abjournals.org

\section{Conceptual Framework}

The study postulates that public consumption expenditure and other determinants of growth variables determine real per capita economic process of East African economies. In between the dependent and explanatory variables are the intervening variables which aren't controlled for. This relationship is conceptualized in Figure 1.

\section{Explanatory Variables}

Consumption expenditure
Terms of trade
Trade Openness
Population growth
Human capital

\section{Dependent Variable}

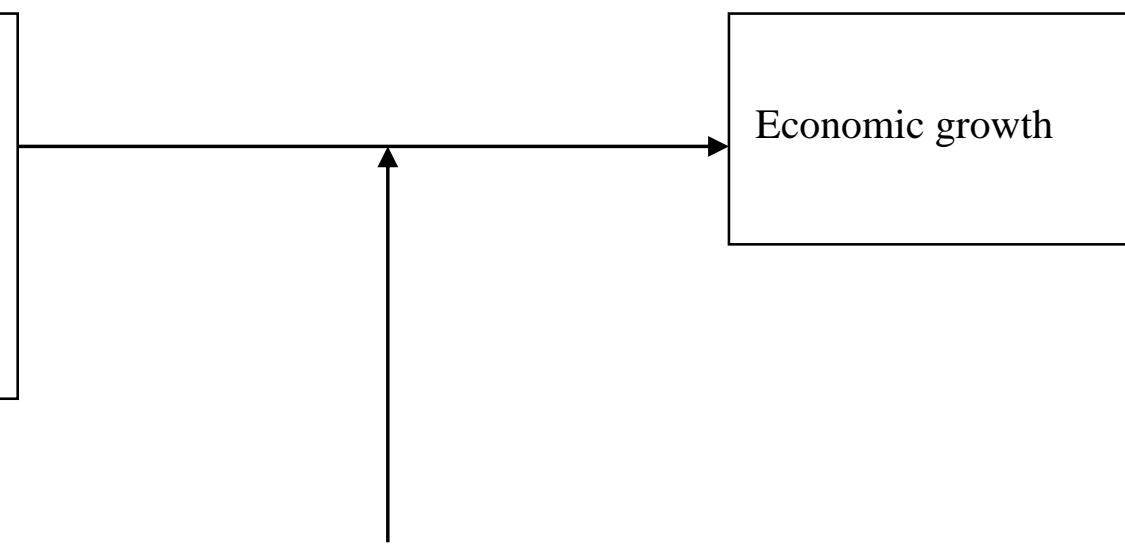

Political instabilities

Environmental factors

Inflation

\section{Intervening Variables}

\section{Figure 1: Conceptual Framework Analysis}

Source: Gisore et al. (2014).

\section{RESEARCH METHODOLOGY}

The study applied a quantitative research design to investigate the impact and trend of public consumption expenditure and economic activities. This was administrated within the period 1985-2015 using panel secondary data and ordinary least squares (OLS) estimation technique. The study was meted out in geographic area countries. Geographical region is found within the continent of Africa within the Sub Saharan region. The geographic area countries considered were Tanzania, Uganda and Kenya. Geographic area economies are located between 5030"N 120S and 28045"E 41050" E. Figure 2 below represents the map for geographical region Countries. 


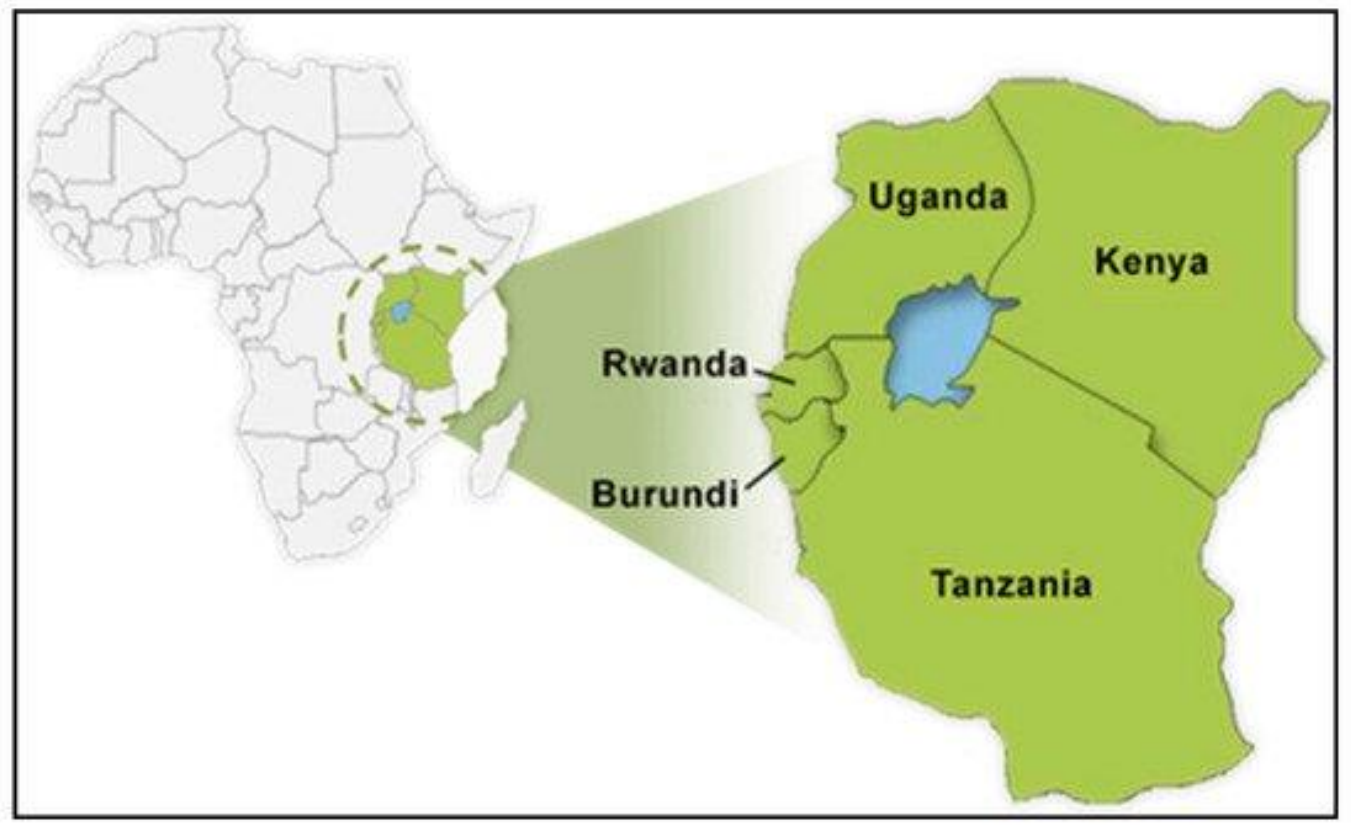

Figure 2: Map of East African Countries.

Source: EAC (2011).

\section{Econometric Model Specification}

Building on Ram (1986), Kweka and Morrissey (1999) and Mose (2021), a simple econometric growth model during which consumption expenditure is explanatory variable was formulated and presented as:

$\ln Y_{i, t}=\beta \ln X_{i, t-1}+\gamma \ln G_{i, t-1}+\mu_{i}+v_{t}+\varepsilon_{i, t}$

Where, $\ln Y_{i, t}$ - the dependent variable - real economic growth

$\ln X_{i, t-1}$ - set of explanatory variables

$\ln G_{i, t-1}$ - the government consumption expenditure variables

$\beta$ and $\gamma$ - are parameters to be estimated

$\mu_{i}-$ country fixed effects $\quad v_{t}-$ time fixed effects $\quad \varepsilon_{i, t}-$ the error term

and the subscripts $i$ and $t$ represent county and time period respectively.

Thus, panel model to be estimated is specified in logarithm form as: 


$$
\begin{gathered}
y=f(r, a, h, t, p, o) \\
\operatorname{lny}_{i, t}=\beta_{0}+\beta_{1} \operatorname{lnr}_{i, t}+\beta_{2} \operatorname{lnh}_{i, t}+\beta_{3} \operatorname{lna}_{i, t}+\beta_{4} \operatorname{lnt}_{i, t}+\beta_{5} \operatorname{lnp}_{i, t}+\beta_{6} \operatorname{lno}_{i, t}+\varepsilon_{i, t}
\end{gathered}
$$

Where, $\ln y_{i, t} \quad$ - Real GDP growth as a proxy of economic growth,

$$
\begin{array}{ll}
\ln r_{i, t} & \text { - Recurrent expenditure as a proxy of consumption expenditure, } \\
\ln h_{i, t} & \text { - School enrollment as a proxy of human capital development, } \\
\ln a_{i, t} & \text { - Aggregate expenditure as a proxy of government total expenditure, } \\
\ln o_{i, t} & \quad-\text { Trade Openness, } \\
\ln t_{i, t} & \text { - Terms of Trade, } \\
\ln p_{i, t} & \text { - Population growth. }
\end{array}
$$

The study constructed secondary panel database with information along three dimensions: The growth variable, the government expenditure variables, and control variables. The panel data was collected from economic review reports, statistical abstracts and World Bank reports.

\section{Panel Data Analysis}

Descriptive and inferential estimation was applied accordingly. The Panel data was estimated using the ordinary least squares (OLS) estimation technique. Hausman (1987) test was applied to support the applying of Fixed or Random effect model. Fixed effect explores the association between predictor and outcome variables within an entity (country, person, company, etc). Macroeconomic statistics data are generally characterised by stochastic trend which might be removed by differencing. This study adopted Levin-Lin-Chu (2002) technique to verify the presence of unit root. Following Engel-Granger cointegartion approach, the study attempted to work out whether long-run relationship exists between the variables. Post-estimation panel diagnostic tests were administered during the study. Heteroskedasticity and serial correlation were analysed for the above models before estimation and corrected accordingly. 
African Journal of Economics and Sustainable Development

ISSN: 2689-5080

Volume 4, Issue 3, 2021 (pp. 61-71)

www.abjournals.org

\section{RESULTS AND DISCUSSIONS}

\section{Descriptive Matrix Result}

Normality test is done to test whether the variables employed in the analysis are normally distributed. The common test for normality is that the Jarque-Bera statistics test (Jarque and Bera, 1980). This test utilises the mean based coefficient of skewness and kurtosis to test the normality of all the variables used. On one hand, Skewness measures the direction and degree of asymmetry. During this study, results indicate normal curves for all the variables, with negative values of skewness indicating a tail to the right except for terms of trade. This suggests that the positively skewed variables were high during the start years but are progressively declining over the years. The negatively skewed variables, shows an increasing trend during the latter years. From the Kurtosis result, all the variables have kurtosis value of less than three which suggests the variables have platykurtosis distribution Bivariate correlation was used to evaluate the degree of relationship. The absolute value of the coefficient of correlation ranges from 0 to 1 . In general, most government expenditure components seem to be positively correlated between themselves.

\section{Panel Econometric Result}

The unit root test was allotted so as to eliminate any possibility of spurious regressions and erroneous inferences. This involved determining the order of integration of the time series through unit root test. Accordingly, Levin-Lin-Chu result's reported in Table 1.

\section{Table 1: Panel Unit Root Test Results}

\begin{tabular}{|c|c|c|c|c|c|c|}
\hline \multirow{3}{*}{$\begin{array}{l}\text { Variables } \\
\text { in Logs } \\
\ln y\end{array}$} & \multicolumn{2}{|c|}{ Levin-Lin-Chu at Level } & \multirow{3}{*}{$\begin{array}{l}\text { Order } \\
\text { I(0) }\end{array}$} & \multicolumn{2}{|c|}{ LLC at First difference } & \multirow[t]{2}{*}{ Order } \\
\hline & Unadjusted $\mathrm{t}$ & Adjusted $\mathrm{t}$ & & Unadjusted $\mathrm{t}$ & Adjusted $\mathrm{t}$ & \\
\hline & -5.53 & -3.28 & & - & - & - \\
\hline $\ln r$ & -2.08 & -0.06 & $\mathrm{I}(1)$ & -7.69 & -5.06 & $\mathrm{I}(0)$ \\
\hline $\ln h$ & -1.13 & 0.78 & $\mathrm{I}(1)$ & -9.07 & -6.25 & $\mathrm{I}(0)$ \\
\hline $\ln a$ & -1.76 & -0.01 & $\mathrm{I}(1)$ & -6.77 & -3.98 & $\mathrm{I}(0)$ \\
\hline $\ln o$ & -1.38 & 0.23 & $\mathrm{I}(1)$ & -6.66 & -3.80 & $\mathrm{I}(0)$ \\
\hline $\ln t$ & -2.70 & -0.18 & $\mathrm{I}(1)$ & -6.36 & -3.19 & $\mathrm{I}(0)$ \\
\hline $\ln p$ & -3.64 & -1.04 & $\mathrm{I}(1)$ & -8.13 & -5.34 & $\mathrm{I}(0)$ \\
\hline
\end{tabular}

The results reveal that each one the variables are non-stationary at level except the variable. However, they become stationary after the primary difference implying that the variables are integrated of order one, I (1). This therefore implies there was no co-integration since the variables are of different integration. 
African Journal of Economics and Sustainable Development

ISSN: 2689-5080

Volume 4, Issue 3, 2021 (pp. 61-71)

www.abjournals.org

The Hausman test results ( $\mathrm{p}$-value is $0.04<0.05$ ) suggest a rejection of the null hypothesis. Hence the null hypothesis is rejected and therefore the fixed panel effect model is chosen. Table 2 reports the results of the regression analysis on the effect of consumption expenditure on economic growth.

Table 2: Fixed Effect Regression Results

\begin{tabular}{|c|c|c|c|c|}
\hline Variable & Coefficient & Standard error & t- Statistics & P-value \\
\hline cons & $4.17 * * *$ & 1.44 & 2.90 & 0.005 \\
\hline $\ln r$ & $-2.30 * * *$ & 0.81 & -2.84 & 0.006 \\
\hline $\ln h$ & $0.53 *$ & 0.30 & 1.76 & 0.220 \\
\hline $\ln 0$ & $0.98^{*}$ & 0.39 & 2.50 & 0.063 \\
\hline $\ln a$ & $0.62^{*}$ & 0.18 & 3.37 & 0.078 \\
\hline $\ln t$ & -1.42 & 0.99 & -1.43 & 0.289 \\
\hline $\ln p$ & $-2.40 * * *$ & 0.09 & -25.42 & 0.002 \\
\hline \multicolumn{2}{|c|}{ Goodness of Fit Test } & $\mathrm{R}^{2}=0.33$ & \multicolumn{2}{|c|}{ AdjustedR $^{2}=0.30$} \\
\hline \multicolumn{2}{|c|}{$F(7,85)=5.862$} & $\mathrm{P}$-value $(\mathrm{F})=0.000$ & \multicolumn{2}{|c|}{ Durbin. $\mathrm{W}=1.9$} \\
\hline \multicolumn{2}{|c|}{ Wooldridge Test } & $\mathrm{F}(1,2)=10.04$ & \multirow{2}{*}{\multicolumn{2}{|c|}{$\begin{array}{l}\text { Prob > F }=0.09 \\
\text { Prob }>\gamma 2=0.71\end{array}$}} \\
\hline \multicolumn{2}{|c|}{ Modified Wald Test } & $\chi^{2}(3)=1.39$ & & \\
\hline Hausman & $=19.64$ & Prob $>\chi^{2}=0.04$ & \\
\hline
\end{tabular}

The regression findings reveal that public recurrent expenditure a proxy for consumption spending is negatively significant in geographic region states in relevancy economic activities at five percent level of significance. This suggests one percent increase in consumption expenditure will translate to about two percent reduction in economic activities. This result supports policy strategy supported by Bretton Woods Institutions (Mitchell, 2005). These institutions recommend a decrease in recurrent spending across the developing countries so as to stimulate growth through fund transfer to infrastructure development. It is said that increased government consumption expenditure is typically at the expense of investment expenditure or the private sector's investment which in most cases results in instances of reduced economic process. Classical theories consider consumption expenditure as ineffective as a result of crowding out effect phenomenon, that is, when private investment is substituted for public investment, this lower private investment and output growth. Because the public sector borrows heavily to fund public expenditure, pressure within the credit market leads to higher interest rate which discourages continued private investment (Barro, 1991).

In contrast, per Keynesian scholars, consumption expenditure can contribute positively to economic expansion through increased purchasing power of the citizens (Romer, 1996). As a result, public consumption spending augments the total demand, which stimulates an increased output betting on expenditure multipliers. With respect to government consumption spending, the results of this study consider the findings obtained by researchers like Barro (1991), Lin (1994) and Gisore et al. (2014). In contrast Josaphat and Oliver (2000) and 
Kweka and Morrissey (1999) reported positive in relation to Tanzania which they related to stimulated private consumption.

From the regression result, for controlled variables, total government expenditure is positively significant. This sort of expenditure may well be related to the productive government expenditure that Barro (1990), Gemmell (2001) and Waweru (2021) noted to be a further input to the private production function. Trade openness is positively significant in geographical area. Trade openness encourages exchange of ideas and technologies which means that the developing countries like Kenya, Uganda and Tanzania can have access to superior technologies and thus output growth (Murphy et al., 1991). Increment is negatively significant at the simple fraction in relevancy growth. Consistent with Barro and Sala-iMartin (2004), increase has exerted a major negative effect on economic process in developing countries through reduced productivity and output per capita. Terms of trade were insignificant at any conventional level of significance. This suggests that primary export remains unproductive as a result of unstable prices (Teshome, 2006).

The coefficient of determination (adjusted R2) shows that 30 per cent of the dependant variable is explained within the model. The $\mathrm{F}$ test result indicates that all the independent variables have explanatory power at $1 \%$ level of significance. The study used Wooldridge test for autocorrelation in panel data. The study concludes that the model doesn't have first-order autocorrelation. The value for Durbin-Watson is equal to 1.9, implying auto correlation isn't a controversy. From above result heteroscedasticity isn't an issue.

\section{CONCLUSION AND RECOMMENDATIONS}

Consistent with theoretical prediction, consumption expenditure has negative effects while aggregate expenditure has positive effects on economic growth. Reducing consumption expenditure to sustain government investment could be a policy recommendation worth pursuing. In contrast, boosting government investment can enhance its complementarities role with private investment and economic process. The governments should increase its own investment in areas that are beneficial to the private sector and move faraway from those who compete with or crowd it out. Within the same vein, any austerity measures geared toward reducing government expenditure shouldn't be achieved by budgetary cuts on development budget, as is usually the case in East Africa, for this reduces government investment. It follows that to realize accelerated economic process and sustainable development, government spending should be specified it creates conducive environment for the private sector development and repairs market failures.

The study cautions the adoption of reduced government spending on consumption expenditure which was found to be a negative determinant of economic process. In keeping with the Keynesian macroeconomic thought, government expenditure can contribute positively to growth by injecting purchasing power into the economy. Hence, a rise within the government consumption is probably going to guide to a rise in employment opportunities, profitability and investment through multiplier effects on aggregate demand. 
African Journal of Economics and Sustainable Development

ISSN: 2689-5080

Volume 4, Issue 3, 2021 (pp. 61-71)

www.abjournals.org

\section{Areas of Further Investigation}

From the findings of this study, there's a necessity for further consumption expenditure data disaggregation into private and public consumption expenditure for deeper policy prescription.

\section{REFERENCES}

Akpan, N. (2005). Government Expenditure and Economic Growth in Nigeria. CBN Economic Financial. Rev.,43(1).

Backhaus, J. (1997). ed. Essays in Social Security and Taxation. Gustav von Schmoller and Adolf Wagner Reconsidered. Metropolis.

Barro, J. (1990). "Government Spending in a Simple Model of Endogeneous Growth". The Journal of Political Economy, Vol. 98, No. 5, S103-S125.

Barro, R. J. (1991). 'Economic growth in a cross section of countries', Quarterly Journal of Economics. 106, 407-444.

Barro, R.J. and Sala-i-Martin, X. (2004). Economic Growth, Cambridge, MA: MIT Press.

Brown, C.V. and Jackson, P. M. (1996). "Public Sector Economics", 4th ed.,Blackwell Publishers Ltd, UK.

EAC. ( 2011). East African Community Figures and facts. Arusha Tanzania.

Gemmel, N. (2001). Fiscal Policy in a Growth Framework. WIDER Discussion Paper.01/84.

Gisore, N., Kiprop, S., Kalio, A., \& Babu, J. (2014). Effect of government expenditure on economic growth in East Africa: A disaggregated model. European Journal of Business and Social Sciences, 3(8), 289-304

Gregorious, A. and Ghosh, S. (2007). The impact of Government Expenditure on Growth:

Empirical Evidence from Heterogeneous panel. Retrieved on 7/6/2021

(http://www.brunel.ac.uk/9379/efwps/0701.pdf).

Hausman, J. (1978). Specification tests in econometrics. Econometrica, 46, 1251-1271.

Jarque, M. and Bera, K. (1980). Efficient tests for normality, homoscedasticity. Math Works.

Josaphat, P. and Oliver, M. (2000). Government Spending and Economic Growth in

Tanzania,1965-996: CREDIT Research Paper.

Kakar, K. (2011). Impact of Fiscal Variables on Economic Development of Pakistan.

Romanian Journal of Fiscal Policy 2, 1-10.

Korman, J. and Bratimasrene, T. (2007), "The relationship between Government Expenditure and Economic Growth in Thailand", Journal of Economic Education, Vol 14. 234-246.

Kweka, P. and Morrissey, O. (1999). "Government Spending and Economic Growth, Empirical Evidence from Tanzania (1965-1996)", CREDIT and Schoolof Economics, University of Nottingham.

Levin, A., Lin, C. F. and Chu, J. (2002). Unit Root Tests in Panel Data: Asymptotic and Finite Sample Properties. Journal of Econometrics, 108:1-24.

Lin, S.A.Y. (1994). "Government Spending and Economic Growth", Applied Economics, 26, 83-94.

Mitchell, J. (2005). The Impact of Government Spending on Economic Growth. Backgrounder, 1831. 
African Journal of Economics and Sustainable Development

ISSN: 2689-5080

Volume 4, Issue 3, 2021 (pp. 61-71)

www.abjournals.org

Mose, N. (2021). Determinants of regional economic growth in Kenya. African Journal of Business Management, 15(1), 1-12

Murphy, K., Shleifer, A. and Vishny, R. (1991). "The Allocation of Talent: Implications for Growth", Quarterly Journal of Economics 106.

Ram, R. (1986). "Government Size and Economic Growth: A New Framework and Some Evidence from Cross-Section and Time-Series Data”. The American Economic Review, 76, No. 1, 191-203.

Romer, D. (1996). "Advanced Macroeconomics", the MacGrow-Hill Co. Inc., Singapore.

Romer, P. M. (1990). Endogenous Technological Change. Journal of Political Economy, 98, 71-102.

Teshome, K. (2006). The Impact of Government Spending on Economic growth: The case of Ethiopia, University Addis Ababa.

Waweru, D. (2021). Government capital expenditure and economic growth: An empirical investigation. Asian Journal of Economics, Business and Accounting, 21(8), 29-36 